\title{
ESETTANULMÁNY ÜZLETI FOLYAMATFEJLESZTÉSRE - IPARI FOLYAMAT RACIONALIZÁLÁSA
}

\section{BUSINESS PROCESS IMPROVEMENT: A CASE STUDY - RATIONALIZATION OF INDUSTRY PROCESS}

\author{
Pusztai László Péter ${ }^{1}$, Kocsi Balázs ${ }^{2}$ \\ ${ }^{I}$ Debreceni Egyetem, Müszaki Kar, Müszaki menedzsment tanszék, 4028, Magyaror- \\ szág, Debrecen, Ótemetö utca 2-4., telefon: +36 30/345-6635, levelezési cím: pusz- \\ tai.laszlo@inf.unideb.hu \\ ${ }^{2}$ Debreceni Egyetem, Müszaki Kar, Müszaki menedzsment tanszék, 4028, Magyaror- \\ szág, Debrecen, Ótemetö utca 2-4., telefon: +36 70/389-2525, ko- \\ csi.balazs@inf.unideb.hu
}

\begin{abstract}
The aim of this paper is to rationalize the product assembly process of a Hungarian small and mediumsized enterprise. During the project we set the goal to decrease the whole process lead time by more than $50 \%$. To get acquainted with the whole assembly process we used the value stream mapping technique, to identify and correct wastes we applied group quality correction tools. Eliminating the main wastes from the process could result in $15 \%$ reduction from the total lead time. We also found that if all the referred wastes could be removed, the total lead time reduction would reach more than $40 \%$.
\end{abstract}

Keywords: root cause analysis, FMEA, VSM, Process model

\section{Összefoglalás}

Tanulmányunk megírása során mezőgazdasági talajlazító gépeket készítő magyar kis és középvállalat összeszerelési folyamatát racionalizáltuk. Ezen idő alatt azt a célt tüztük ki magunk elé, hogy folyamatdiagnosztikával az összeszerelési folyamat teljes átfutási idejét legalább 50\%-kal csökkentsük. A folyamat megismerésére értékáram térképet, a veszteségek megfigyelésére és kijavításukra csoportos minőségjavító módszereket alkalmaztunk. A fejlesztési projekt végeztével arra jutottunk, hogy bizonyos hibák kiküszöbölésével a folyamat teljes átfutási idejét közel 15\%-kal, míg a vizsgálat során feltárt összes veszteség eliminálásával a teljes folyamat átfutási idö több, mint 40\%-kal redukálható.

Kulcsszavak: gyökérok elemzés, hibamód és hatáselemzés, értékáram térkép, folyamatmodell

\section{Bevezetés}

Minden vállalat elsődleges célja, hogy a vevői igényeket teljes körüen kielégítse. Azonban, a vevői igények egyre növekednek a globalizálódó világnak köszönhetöen. Egy megrendelés teljeskörü kiszolgálásához három szempontnak kell megfelelni: a termék elöállítási költsége, minősége, vala- mint a szállítás megbízhatósága. Tanulmányunkban egy mezőgazdasági vontatmányok összeszerelésével foglalkozó vállalat termelési folyamatát elemeztük és a hatékonyság növelése érdekében hoztunk javító intézkedéseket. Amely intézkedések előbb említett aspektusok közül a termék minőségének javítását, valamint folyamat előállítási költség csökkentését célozta. 


\section{Folyamatfejlesztési technikák}

Számos fogalmi meghatározás született a folyamat definíciójára, melyböl talán a legszélesebb körben ismert és elismert változat az ISO 9001-es szabványé: ,egymással kapcsolatban vagy kölcsönhatásban álló tevékenységek olyan sorozata, amely bemeneteket kimenetekké alakit át" [1].

Michael Porter szerint a töretlenül fejlödő üzleti életben azok a vállalatok maradhatnak versenyképesek, amelyek kiemelt szerepet tulajdonítanak a termékeik megkülönböztetésére (differenciáló stratégia), vagy a fókuszát a folyamatok fejlesztésével elérhető költségelőnyökre helyezi (költségvezető stratégia) [2]. Utóbbira számos elmélet született a nemzetközi szakirodalomban, kiemelve a kaizent, a folyamatok újjászervezését (BPR), továbbá az üzleti folyamatok menedzsmentjét (BPM).

\subsection{Kaizen}

A kaizen egy japán szó, jelentése kai = változtatás, zen $=$ jó, vagyis jó irányba való változtatás. Ez egy olyan folyamat hatékonyságát javító gondolkodásmód, amelynek két fó alapelve a fejlesztések kis ütemben való végrehajtása, valamint az, hogy a fejlesztésből mindig mindenki kiveszi a részét. Hatására a szervezet emberközpotúvá válhat, ahol az emberek pontosan tudják, a folyamat melyik pontjáért felelösek [3].

\section{2. Üzleti folyamatok újjászervezése (BPR - Business Process Reengineering)}

Az üzleti folyamatok újjászervezésének középpontjában az a feltevés áll, hogy a termelésben jelenlévő munkamegosztás okozza a folyamat túlbonyolítását. Az újjászervezés során a folyamat felülvizsgálatra kerül, a felesleges komplexitás megszüntetve optimálisabb müködés biztosítható [4].

\section{3. Üzleti folyamatok menedzsmentje (BPM - Business Process Manage- ment)}

A többi eszközhöz hasonlóan az üzleti folyamatok menedzsmentjének is elsődleges feladata a vállalati múködés folyamatos irányítása, teljesítményének mérése, és a folyamatok fejlesztése. Folyamatmenedzsment projektek irányulhatnak a termékminőség növelésére, selejtarány csökkentésére, a folyamatok teljes átfutási idejének redukálására [5].

\subsection{Minőségfejlesztő technikák}

Modellnek hívjuk a valóság egyszerüsített, a vizsgálat szempontjából kiemelt fontossággal bíró tulajdonságait kiemelő mását. Használatával a döntéshozók pontosabb képet kaphatnak a folyamatról, a tevékenységek kapcsolatáról, ezzel megkönnyítve a döntéshozást [6]. A folyamatmodellezés a Japán ipari menedzsmentböl ismert módszere az értékáram térkép, mellyel jelen, jövőállapot és ideális állapot is leírható.

$\mathrm{Az}$ értékáram térképezés során észrevett veszteségek értékelésére kvalitatív minőségfejlesztő technika alkalmazása ajánlott, amelynek a neve hibamód- és hatáselemzés. A módszer használata során a lehetséges hibákat súlyosság, bekövetkezési valószínüség, és detektálhatóság alapján értékelik. Ezen paraméterek értéke 1-10 közé esik, melyeket összeszorozva összehasonlíthatóvá teszik a lehetséges problémákat:

$$
\begin{aligned}
& \mathrm{RPN}=\mathrm{S} * \mathrm{O} * \mathrm{D} \text {, ahol } \\
& \mathrm{S}=\text { hiba súlyossága; } \\
& \mathrm{O}=\text { hiba bekövetkezési valószínüsége; } \\
& \mathrm{D}=\text { hiba detektálhatósága. [7] }
\end{aligned}
$$

\section{Elemzési módszer}

A vizsgálat első lépése az összeszerelési folyamat megismerése volt: beszélhettünk az operátorokkal, kipróbáltunk pár tevékenységet. Az azonosított tevékenységeket értékáram térképre vetettük, a teljesség miatt minden egyes tevékenység idejét lega- 
lább 5 alkalommal lemértük és beépítettük a modellünkbe. Egy, a munkásokból és mérnökökből álló szakértői csoporttal veszteségvadászatot végeztünk, ahol számos veszteségre akadtunk. Ezeket a veszteségeket felvezettük a hibamód- és hatáselemző táblázatba, minden szempont szerint értéket adtunk nekik. Az így kialakult értékek alapján Pareto-elemzéssel sorrendbe állítottuk, majd csoportra bontottuk a nem értékadó tevékenységeket. A hibákra gyökérok elemzést, és brainstorming csoportos minőségjavító eszközöket alkalmaztunk. A kutatás utolsó lépésekén a csoport által kitalált javítóintézkedéseket beültettük a gyakorlatba, új méréseket végeztünk, és elkészítettük a jövőállapot térképet.

\section{Kutatás eredménye}

A gép egyes alkatrészeit, félkész termékeinek gyártását a vállalat tulajdonosi körébe tartozó vállalat végzi.

A vizsgálat ideje alatt a vállalat 25 talajlazító vontatmány összeszerelésére kapott megrendelést. A terepszemlén 6 előszerelési és 15 összeszerelési tevékenységet különböztettünk meg. A vizsgált cég kérésére a mérések értékeit torzítottuk, így folyamat teljes átfutási ideje 36045 időegység volt. Az adatok mérése és összesítése után elkészítettük a folyamat jelenállapot térképét.

A térkép elemzését, és a veszteségvadászatot követően megvizsgáltuk a veszteségeket, és hibamód- és hatáselemzéssel megvizsgáltuk a hibák fontosságát a folyamatban.

Az itt kapott értékek inputként szolgáltak a Pareto-elemzéshez. Mivel az A és B csoport relatív súlya nagy, ezért ezzel a két csoporttal foglalkoztunk a továbbiakban. A két kategóriát más aspektusból is megközelítve szétbontható külső és belső problémákra a folyamatban. A belső hiba a folyamaton belüli problémákat jelölik (darura várakozás, csapágyak kibontása, stb.), míg a külső a vállalat tevékenységi- és hatáskö- rén kívül felmerült problémákat, melynek forrása a beszállító, aki résztulajdonos a cégben (késés, rossz elökészítés és minőségileg hibás termékek).

1. táblázat: A feltárt veszteségek hibamód és hatáselemzésén meghatározott értékei, valamint Pareto-analizis kategóriái szerint

\begin{tabular}{|c|c|c|}
\hline Hiba megnevezése & Kategória & Érték \\
\hline $\begin{array}{c}\text { Csapágyak } \\
\text { kibontásának } \\
\text { hatékonysága }\end{array}$ & „A” & 200 \\
\hline Beszállító késése & „A” & 216 \\
\hline $\begin{array}{c}\text { Minőségileg hibás } \\
\text { alkatrészek }\end{array}$ & „A” & 210 \\
\hline $\begin{array}{c}\text { Nem megfelelő } \\
\text { elökészítés }\end{array}$ & „B” & 180 \\
\hline Darura várakozás & „B” & 144 \\
\hline $\begin{array}{c}\text { Nem megfelelő } \\
\text { szerszámok }\end{array}$ & „B” & 72 \\
\hline Rossz tervrajz & „C” & 48 \\
\hline $\begin{array}{c}\text { Szerszámmal való } \\
\text { ellátottság }\end{array}$ & „C” & 36 \\
\hline $\begin{array}{c}\text { Alkatrészek rossz } \\
\text { beépítése }\end{array}$ & „C” & 24 \\
\hline Raklapméret hibája & „C” & 21 \\
\hline
\end{tabular}

A fenti „A” és „B” kategóriás problémákra csoportos minőségjavító eszközöket alkalmazva meghatároztuk a javítóintézkedéseket:

- csapágyak kibontásának hatékonyságát egy több csapágyat tartalmazó csomagolás bevezetését javasolnánk;

- a darura várakozás veszteségét daruzási tevékenységek kiiktatásával vagy más eszközzel való felváltásával küszöbölnénk ki;

- megfelelő minőségü és mennyiségű szerszám beszerzése;

- a külső hibák esetében pedig biztonsági készlet tartását és jobb információáramlás megvalósítását javasoljuk, így nem jelenthet gondot a késedelmes szállítás, és a minőségileg nem kielégítő alkatrészek átvétele sem lenne kötelező. A probléma feloldására pedig beszállító-fejlesztési projektet javaslunk. 
A javítóintézkedéseket a gyakorlatba ültetve megállapítható volt, hogy az eredeti folyamat átfutási időhöz képest (1. ábra 1. oszlop) a belső hibák kiküszöbölésével a teljes átfutási idő közel 15\%-kal csökkenthető (1. ábra 2. oszlop), míg ha a külső hibákra megoldást találnak, akkor a folyamat teljes átfutási ideje 42\%-kal lehetne csökkenthetö (1. ábra 3. oszlop):

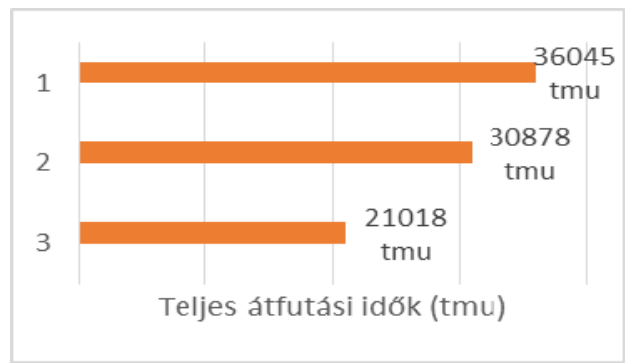

1. ábra: Teljes átfutási idők vizsgálata

\section{Következtetések}

A kutatás célja egy magyar kis és középvállalkozás folyamatának racionalizálása volt egyszerü, költséghatékony folyamatfejlesztő eszközök segítségével. A cikkben ismertetett esettanulmány példaként szolgálhat minden olyan vállalat számára, akik úgy gondolják, hogy nem lehetséges a folyamatjavítást magas költségek nélkül megvalósítani.

\section{Szakirodalmi hivatkozások}

[1] MSZ EN ISO 9001:2015,

[2] Michael Porter: Competitive Strategy: Techniques for Analyzing Industries and Competitors. The Free Press, New York, 1980.

[3] Michael Baudin: Working with machines: The nuts and bolts of lean operations with Jidoka. Productivity Press, New York, 2007. p 107.

[4] Yih-Chang Chen: Empirical modelling for Participative Business Process Reengineering. University of Warwick, Coventry, 2001.

[5] Jan vom Brocke, Michael Rosemann: Handbook on Business Process Management, Springer Heidelberg, London, 2010.

[6] Pokorádi László: Rendszerek és folyamatok modellezése. Campus Kiadó, Debrecen, 2008.

[7] D. H. Stamatis: Faulure Mode Effect Analysis: FMEA from Theory to execution. Quality Press, Milwaukee, 2003. 